\title{
The Maiganga Coal Deposit: Bituminous, Sub-Bituminous or Lignite?
}

\author{
Chibuisi Samuel Ikwuagwu ${ }^{1, *}$, Maduabuchi Uche Uzoegbu ${ }^{2}$ \\ ${ }^{1,2}$ Department of Geology, College of Physical and Applied Sciences, Michael Okpara University of Agriculture, \\ Umudike, Umuahia, Nigeria
}

\begin{abstract}
There has been varying conclusions on the rank of coal at Maiganga over the years. This paper examined the Maiganga coal with the aim of establishing its actual rank. Proximate analysis was undertaken on some samples from Maiganga coal mine. The analysis determined the percentage moisture content, volatile matter, fixed carbon, ash content, and calorific value. Although not directly relevant for the determination of the rank of coal, the total sulfur of the coals was evaluated also. The Maiganga A1 and Maiganga A2 samples were from the first seam. Maiganga B1 and Maiganga B2 were collected from seam two of the coal deposit. From the result of the analysis the coal has high percentage ash content, moisture content, volatile matter, and low fixed carbon and calorific value. Based on the result of this analysis and on the coal classification by the American Society for Testing and Materials (ASTM), this paper establishes that the Maiganga coal falls within the lignite rank.
\end{abstract}

Keywords: Proximate analysis, Maiganga, Coal, Lignite, Fixed Carbon

\section{Introduction}

The unconsolidated accumulation of debris [1] in geological conditions and time, under metamorphic process led to the formation of coal. The cycles of accumulation and sediment deposition continued [2], followed by diagenetic and tectonic [3] activity for coal to form. The extent of temperature, pressure, and time determines the degree of transformation the coal undergoes, which indicates the various ranks of coal. Depending on the degree of transformation [4-5], or metamorphism [6], coal is separated into four ranks, namely; lignite (brown coal), subbituminous, bituminous, and anthracite. Whereas anthracite, which is the hardest of the ranks, is established to have undergone a full cycle of metamorphism [7-8], lignite is established to be at the early stage of the metamorphic process. Hence, it is not well developed, as it is very soft, can ignite spontaneously under appropriate conditions, dusty, and has low calorific value.

Chemical analysis is undertaken to establish the rank of every coal occurrence, mostly to determine the quality of the coal. Proximate analysis [9] is used to determine the percentage of volatile matter, ash content, moisture (inherent water) content, and fixed carbon composition of coal sample. Fixed carbon, it must be noted is solid, combustible matter left in coal after the lighter, volatile, hydrogen-rich compounds are driven off during coalification [10-12]. This evaluation of coal quality [13] is majorly to ascertain coal use.

The Maiganga coal occurrence [14], which is formed in the Gombe sandstone has been a subject of investigation for decades with varying conclusions on the rank, quality of the coal [15]. Hence, the area was geologically mapped by this study, samples collected at the Maiganga coal mine were analyzed, using proximate analysis in order to establish the rank, and by extension its quality and use. Therefore, the aim of this study is to determine the rank of the Maiganga coal.

\section{Geological Settings Of Maiganga}

Maiganga lies within the Gombe sandstone, adjacent to and above the Pindiga Formation [16]. Whereas the Pindiga Formation was deposited under marine condition, the Gombe sandstone was laid down in non-marine, possibly delta plain condition. Geological mapping shows that actually being of the Upper Continental Sequence, the Gombe Sandstone is a sequence of estuarine and deltaic sandstones, siltstone, shale [17] and ironstones which overlie the sediments of the Zambuk ridge and the Chad Basin in the western part of the region. The restricted outcrop of the Gombe Sandstone suggests that these rocks were deposited in a basin which lay to the west of the Zambuk ridge in late Cretaceous times [18].Siltstones and flaggy sandstones form greater part of Gombe Sandstone. These rocks are soft and light grey in colour when fresh, but on exposure give rise to dark red, flaggy debris which characteristically mantles the Gombe Sandstone hills. The Gombe Sandstone is the top member of a folded and eroded sedimentary sequence and it is not possible to determine its original thickness, at least 1,000 ft. of strata are 
present in the area.An unconformity may exist below the Gombe Sandstone. Its contact with the Pindiga Formation and Fika shales is never satisfactorily exposed and in the field conclusive evidence of an unconformity has not be obtained. However, the presence of an unconformity is suggested by differences in structure between the Gombe Sandstone and the older Cretaceous rocks; the Gombe Sandstone is neither strongly folded nor does it reflect the east-west trends which are imposed on the earlier formation. Maiganga coal mine exposes the rock units of the Gombe Sandstone. And obviously the Gombe Sandstone is the formation that hosts most of the coal deposits found in Gombe State, especially that of Maiganga.

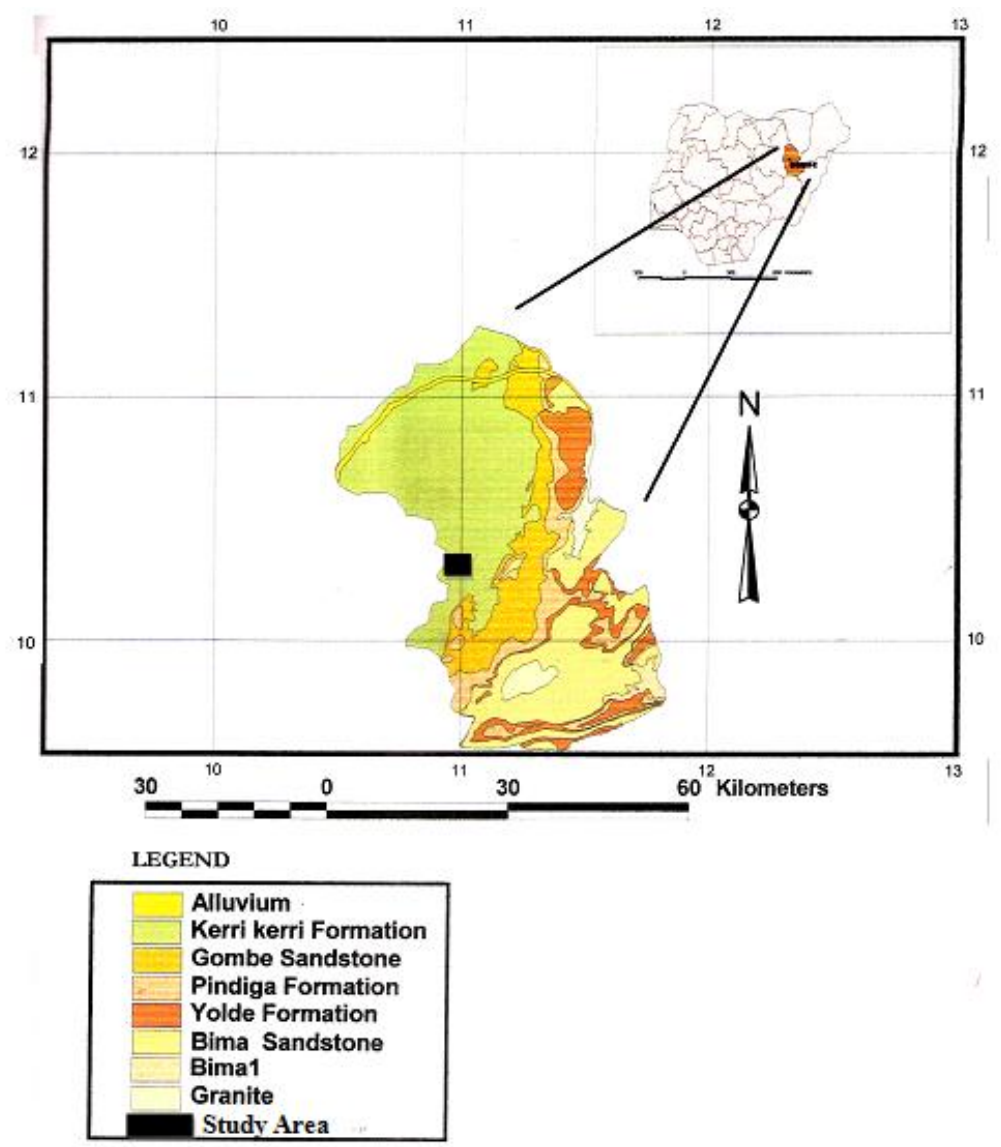

Fig. 2.1: Map of Nigeria showing the geological map of Gombe State

\section{Materials And Methods}

All necessary literatures and works published on the study area were acquired. Different maps were also acquired and carefully studied, thereby marking out the area of concern. With these, the mapping exercise was planned and carried out systematically [19-20]. Appropriate equipment necessary for the exercise were used throughout the geological mapping. Detailed geological mapping took place at Maiganga and environs (Fig. 4.1), and un-weathered in situ samples collected for further study. Stream channels and Wells served as the only means of exposure of the Gombe Sandstone until at the Maiganga coal mine were the formation is clearly exposed. Sandstone, shale and coal samples were all collected at various locations. Five coal samples were then analyzed for the chemical properties to determine their quality.

Two samples each were collected from the two coal seams; A and B being exposed and mined at the Maiganga coal mine. Particularly, the samples were collected at location $1\left(L_{1}\right)$ and stops 1-4 $\left(S_{1}, S_{2}, S_{3}\right.$, and $\left.S_{4}\right)$ as indicated at fig. 4.1. The fifth sample, which was not from Maiganga was only used for correlation. Each of the seams is $3 \mathrm{~m}$ thick, separated by clay. They lie in a lenticular form, trending north-west of Maiganga. Having pulverized each of the coal samples collected from various locations in the coal mine, they were packaged and welllabeled Maiganga A1, A2, B1 and B2; then analyzed. The Maiganga A1 and A2 are from different locations on seam A and Maiganga B1 and B2 are from seam B. 


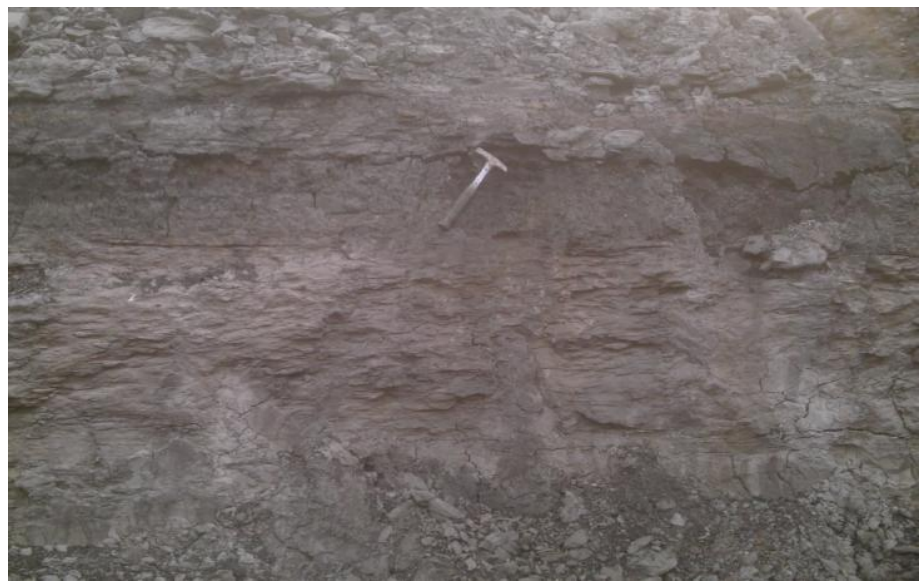

Fig. 3.1: Coal in the Maiganga Coal mine-Seam A

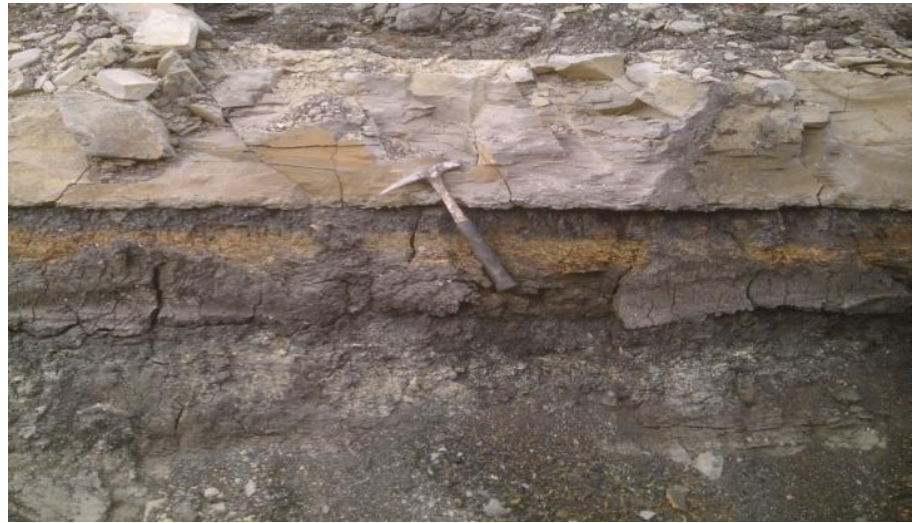

Fig. 3.2: coal intercalated with clay at the Maiganga coal mine

\subsection{Coal Proximate Analysis}

The objective of coal proximate analysis is to determine the amount of fixed carbon, volatile matter, moisture content, and ash content within the coal sample. The variables are measured in weight percent (wt. \%) and are calculated in several different bases. The most widely used in industrial applications is the as received (AR) basis. All variables are put into consideration and the total weight is used as the basis of measurement in the AR basis. The presence of moistures other than inherent moisture in the air dried basis (AD) are neglected, while all moistures, including inherent moisture, surface moisture, and other moisture are left out in the dry-basis (DB). All moistures and ash constituent [21] in the coal are neglected in the dry, ash-free (DAF) [22], while the presence of moisture and mineral matters in coal such as quartz, calcite, pyrite, etc are left out in dry, mineral-matter-free (DMMF ). Based on the ultimate and proximate analysis, mineral matter [23] is not directly measured but may be obtained by one of number of empirical formula. The various proximate analyses require a significant amount of laboratory equipment and is time consuming.

\subsubsection{Moisture Content}

This is determined by heating an air-dried coal sample at $105^{\circ} \mathrm{C}-110^{\circ} \mathrm{C}\left(221^{0}-230^{\circ} \mathrm{F}\right)$ under specified conditions until a constant weight is obtained.

Materials: Crucible, oven, balance, tong, desiccators and 5 prepared coal samples.

\section{Method:}

1. Weigh empty clean crucible as $\mathrm{Wt}_{1}$.

2. Weigh $1 \mathrm{~g}$ of coal sample, $\mathrm{Wt}_{2}$ into the crucible. Weight of crucible + sample is recorded as $\mathrm{Wt}_{3}$.

3. Introduce the crucible + sample into the oven at $110^{\circ} \mathrm{C}$ and leave for one hour.

4. Remove from oven, cool in the desiccators and re-weigh. This is recorded as $\mathrm{Wt}_{4}$.

Weight of moisture content $=\mathrm{Wt}_{3}-\mathrm{Wt}_{4}$

Percentage of moisture $=\underline{\mathrm{Wt}}_{3}-\mathrm{Wt}_{4} \times 100$

$\mathrm{Wt}_{2}$ 
The Maiganga Coal Deposit: Bituminous, Sub-bituminous or Lignite?

\subsubsection{Volatile Matter}

The volatile matter of coal is determined by rigidly controlled standards. This involves heating the coal sample to $900 \pm 5^{\circ} \mathrm{C}\left(1650 \pm 10^{\circ} \mathrm{F}\right)$ for 7 minutes in a cylindrical silica crucible in a muffle furnace in Australian and British laboratories. American standard procedures involves heating to $950 \pm 25^{\circ} \mathrm{C}\left(1740 \pm 45^{\circ} \mathrm{F}\right)$ in a vertical platinum crucible. These two methods give different results and thus the method used must be stated. Here, the former is used.

Materials: Crucible, furnace, tong, balance, desiccators, and 5 prepared coal samples.

\section{Method:}

1. Weigh empty clean crucible as $\mathrm{Wt}_{1}$

2. Weigh $1 \mathrm{~g}$ of coal sample, $\mathrm{Wt}_{2}$ into the crucible. Weight of crucible + sample is recorded as $\mathrm{Wt}_{3}$.

3. Introduce the crucible + sample into the furnace at a temperature of $900^{\circ} \mathrm{C}$ and leave for 7 minutes

4. Remove from furnace, cool in the desiccators and re-weigh, record as $\mathrm{Wt}_{4}$

Weight of volatile matter $=\mathrm{Wt}_{3}-\mathrm{Wt}_{4}$

Percentage of volatile matter $=\underline{\mathrm{Wt}}_{3}-\mathrm{Wt}_{4} \times 100$

\subsubsection{Ash Content}

$$
\mathrm{Wt}_{2}
$$

Coal sample is thoroughly burnt and the ash material indicated as a percentage of the original weight, hence making the analysis a fairly straight forward one.

Materials: Crucible, furnace, tong, balance, desiccators, and 5 prepared coal samples.

\section{Method:}

1. Weigh empty clean crucible as $\mathrm{Wt}_{1}$

2. Weigh $1 \mathrm{~g}$ of coal, sample, $\mathrm{Wt}_{2}$ into the crucible. Weight of crucible + sample is recorded as $\mathrm{Wt}_{3}$.

3. Introduce the crucible + sample into the furnace at temperature of $825^{\circ} \mathrm{C}$ and leave for one hour.

4. Remove from furnace, cool in the desiccators and re-weigh, record as $\mathrm{Wt}_{4}$.

Weight of ash content $=\mathrm{Wt}_{4}-\mathrm{Wt}_{1}$

Percentage of ash $=\mathrm{Wt}_{4}-\mathrm{Wt}_{1} \times 100$

\subsubsection{Fixed Carbon}

$$
\mathrm{Wt}_{2}
$$

This is simply arithmetic. It is determined by subtracting the percentages of moisture, volatile matter, and ash from the samples, i.e. $100 \%-\%$ moisture $+\%$ volatile matter $+\%$ ash .

\subsubsection{Calorific Value}

Calorific value, strictly speaking is neither part of the proximate analysis nor part of the ultimate analysis. It is in fact, one of the many physical properties of coal and is therefore discussed under it in several instances. For the analysis of coal, the calorific value is determined in a bomb calorimeter by either a static (isothermal) or an adiabatic method. In the isothermal method (ASTM D 3286; ISO 1928), a weighed sample of coal is burned in oxygen under controlled conditions and the calorific value is computed from temperature observation made before, during and after combustion, with appropriate allowances made for the heat contributed by other processes. The adiabatic method (ASTM D2015; ISO 1928) consists of burning the coal sample in an adiabatic bomb calorimeter under conditions. The calorific value is calculated from observations made before and after the combustion. The computed value for the calorific value of coal is usually expressed in British thermal units per pound, kilocalories per kilogram, or kilojoules per kilogram $(1.8 \mathrm{Btu} / \mathrm{lb}=1.0 \mathrm{Kcal} / \mathrm{kg}=4.187 \mathrm{Kj} / \mathrm{kg})$.

Materials: Crucible, bomb calorimeter (Leco AC-350), balance, 200ml water, and 5 prepared coal samples.

\section{Method:}

1. Weigh $1 \mathrm{~g}$ of sample into the crucible.

2. Introduce into the combustion chamber, the crucible does not touch the bottom of the combustion chamber.

3. Put the combustion chamber + crucible + sample into the bomb and place into the container that has the $200 \mathrm{ml}$ of water inside the calorimeter. The stirrer under the cover of the bomb calorimeter ensures even distribution of the heat as it automatically stirs.

4. After 8 minutes, the reading is taken from the computerized readings by a side of the bomb calorimeter.

\subsubsection{Total Sulfur}

The samples were analyzed for total sulphur with the computerized XRF equipment. And the press method was employed.

Materials: Computerized XRF, sample cups, sample tray, printer, pistil, and 5 prepared coal samples.

\section{Method:}

1. Put on the computer and the printer after which you turn the key of the XRF clockwise. The machine will take about 2 hours to butt. Then click MINIPAL (the model of the machine) on the monitor to open. 
2. Measure about $3 / 4$ of the sample into the sample cup. Use the pistil to press it in order to remove any air, cover and put on one of the sample positions in the tray (the tray has 12 sample positions). Select the sample position and label name on the screen.

3. Click MEASURE, as the tray appears, click the sample position, the $1 \%$ position on the system is selected for it to start the analysis. The result is displayed as it gets to the $100 \%$ mark.

4. Then the result recorded..

Note: Before you open the x-ray tube, it must be on the reference, $\mathrm{R}$ mark if not it will leak and kill the person instantly. And make sure the machine is not analyzing another sample at the moment

\section{Result And Discussions}

The results obtained in proximate and sulfur analysis from the coal samples are presented in table [4.1] and Table [4.2] below.

Table 4.1: Proximate Analysis of Maiganga Coal

\begin{tabular}{|l|l|l|l|l|l|l|}
\hline S/N & Coal source & $\begin{array}{l}\text { Moisture } \\
\text { content } \\
\%)\end{array}$ & $\begin{array}{l}\text { Ash content } \\
(\text { wt. \%) }\end{array}$ & $\begin{array}{l}\text { Volatile } \\
\text { matter }(\text { wt. } \\
\%)\end{array}$ & $\begin{array}{l}\text { Fixed } \\
\text { carbon } \\
\text { (wt.\%) }\end{array}$ & $\begin{array}{l}\text { Calorific value } \\
(\mathrm{j} / \mathrm{g})\end{array}$ \\
\hline 1. & Maiganga A1 & 5.51 & 19.30 & 42.53 & 32.66 & 4981.5 \\
\hline 2. & Maiganga A2 & 4.41 & 31.34 & 35.53 & 28.71 & 4237.5 \\
\hline 3. & Maiganga B1 & 3.77 & 44.00 & 31.92 & 20.31 & 3200.3 \\
\hline 4. & Maiganga B2 & 3.12 & 48.48 & 25.61 & 22.79 & 2248.8 \\
\hline
\end{tabular}

Table 4.2: Total Sulfur Determination of Maiganga Coal

\begin{tabular}{|c|c|c|c|c|}
\hline \multicolumn{5}{|l|}{ Coal Source } \\
\hline Maiganga A1 & & Maiganga A2 & Maiganga B1 & Maiganga B2 \\
\hline Total Sulfur(wt. \%) & 0.35 & 0.96 & 0.79 & 0.77 \\
\hline
\end{tabular}

Various wells drilled at the Maiganga coalfield shows that the coal occurrence has different depths at which it is encountered. Two seams, A and B being exposed and mined at the Maiganga coal mine. The seam A $\left(\mathrm{L}_{2}, \mathrm{~S}_{1}\right.$ of fig. 4.1) is about $3 \mathrm{~m}$ thick. It is generally of low quality compared to seam $B\left(\mathrm{~L}_{2}, \mathrm{~S}_{2}\right.$ of fig. 4.1) judging by its woody nature and brown coloration. Its hardness increases towards the basaltic hill, north of the mine, which suggests of the effect of the volcanic activity with peculiar characteristics in its geological setting of excessive tectonic shattering and deformation resulting from tensile and compressive stresses [24] typical of the Benue trough. Seam B $\left(\mathrm{L}_{2}, \mathrm{~S}_{2}\right.$ of fig. 4.1), which lies about $5 \mathrm{~m}$ to seam $\mathrm{A}$ is an improvement in quality to that of the former, in that it is much darker in colour and less woody. Obviously the thickness of the coal occurrence here is not uniform, hence difficult to give a general, uniform thickness.

Table (4.1) shows a non-uniform coal quality even among the samples from the same seam. This, notwithstanding, the result shows that the Maiganga A1, A2 and Maiganga B1 and B2 are within the same rank. Based on the classification of laboratory analysis by the American Society for Testing and Materials (Table 4.3), coals are classified based on fixed carbon content, volatile matter content, moisture and ash [25]. By this they are grouped into different ranks; lignite, sub-bituminous, bituminous, and anthracite. Each of these ranks have value limit within which a coal sample falls into. In some cases however, the fixed carbon and calorific values are strictly used. For instance, a result of analysis of a coal sample that falls within $8,300 \mathrm{Btu} / 1 \mathrm{~b}$ to $6,300 \mathrm{Btu} / 1 \mathrm{~b}$ is placed as lignite A (Table 4.3) whereas the sample that has a calorific value of less than $6,300 \mathrm{Btu} / 1 \mathrm{~b}$ is lignite $\mathrm{B}$. The fixed carbon of lignite is normally $60 \%$ and less. 


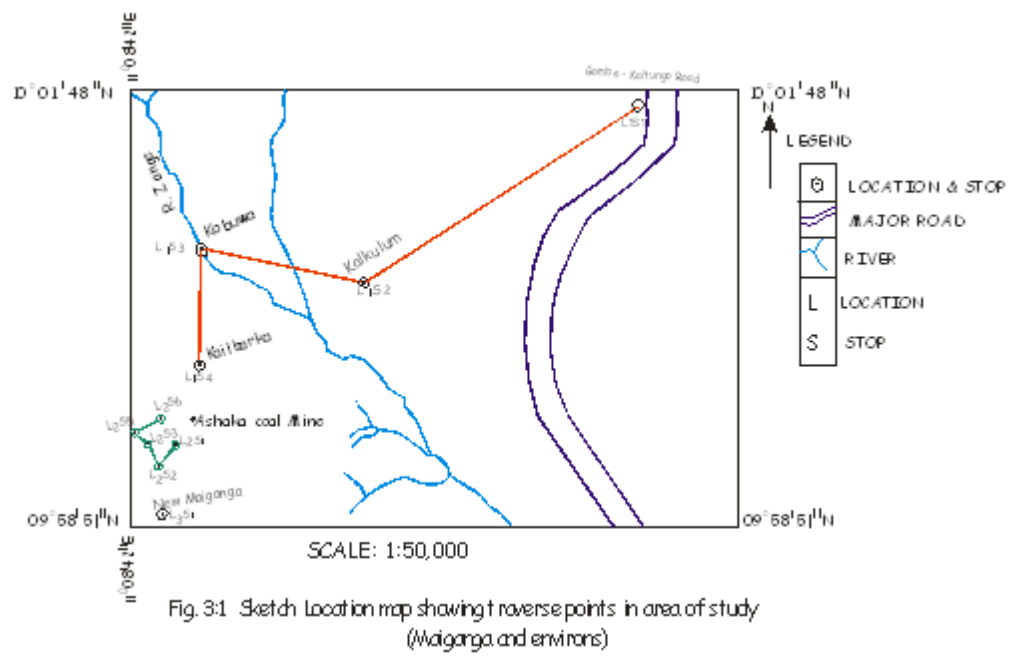

Table 4.3: Coal Classification by ASTM D388 (1997)

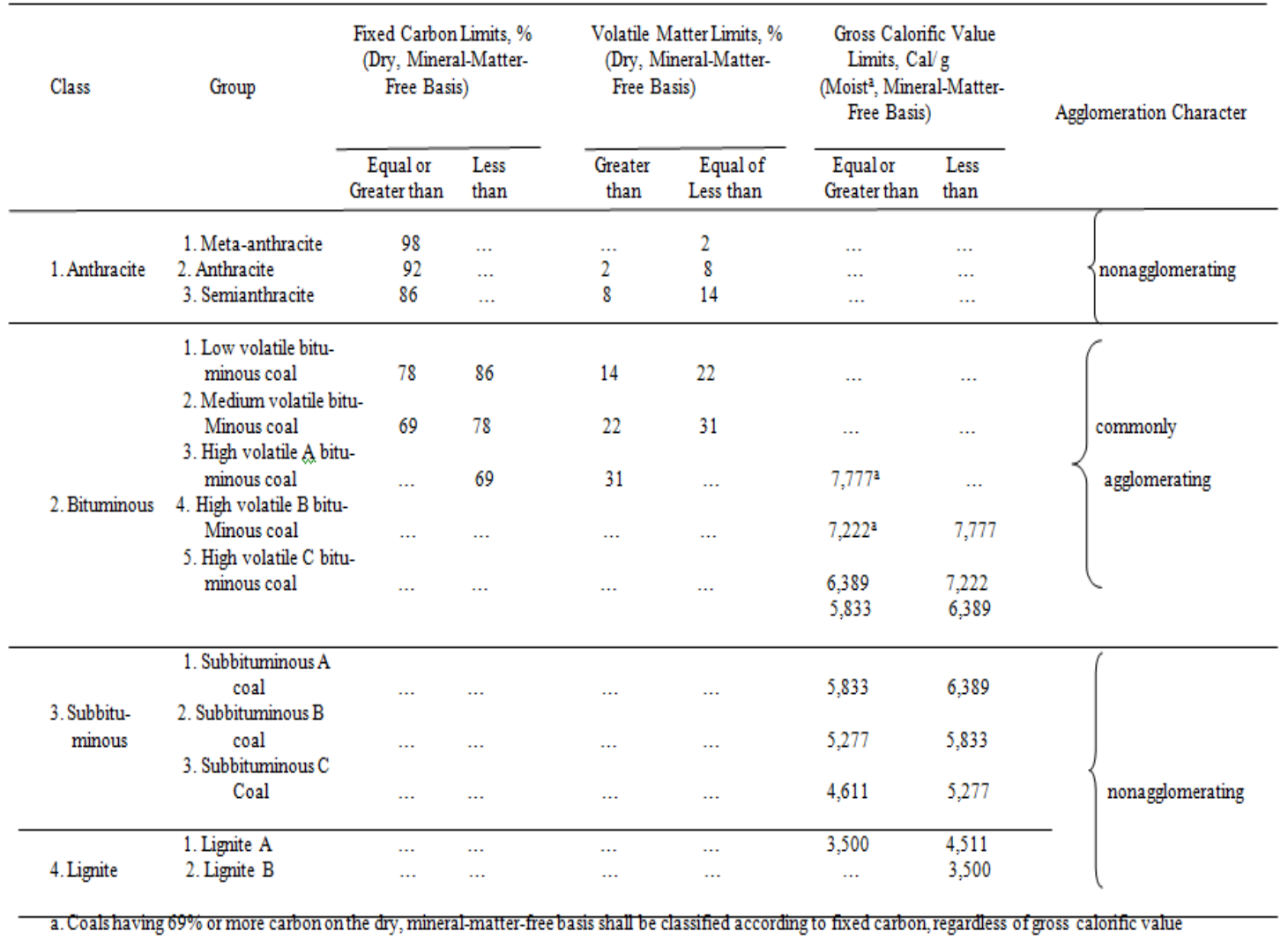

b. This classification applies to coals composed mainly of volatile. Coal rich in liptinite or inertinite do not fit into this classification

c. Moist refers to containing its natural inherent moisture but not including visible water on the surface coal

d. if agglomerating, classify in low-volatile group of the bituminous class

e. It is recognized that there may be nonagglomerating varieties in these groups of the bituminous class, and that there are notable exceptions in high volatile $\mathrm{C}$ bituminous group

Source: ASTM Standards D388 (1997) 
The Maiganga Coal Deposit: Bituminous, Sub-bituminous or Lignite?

\subsection{The Rank of Maiganga Coal}

Looking closely at the result (Table 4.1) and based on ASTM coal classification (Table 4.3), the Maiganga coal apparently falls within the lignite rank [26-27], as this is the range of its calorific value and fixed carbon. Samples from locations A1 and A2 have $4981.5 \mathrm{j} / \mathrm{g}$ and $4237.5 \mathrm{j} / \mathrm{g}$ calorific values. Their fixed carbon values are $32.66 \%$ and $28.71 \%$ respectively. The locations B1 and B2 have 3200.3j/g and 2248.8j/g respectively as their calorific values, whereas $20.31 \%$ and $22.48 \%$ are their respective fixed carbon values. By far, the most important property of coal is that it burns. When pure carbon and hydrocarbons found in coal burn completely only two products are formed: carbon-dioxide and water. During the chemical reaction, a relatively large amount of heat energy is released, the very reason why coal has been used as energy source. This is the reason why carbon content of coal is very important and its quantity in a coal determines how it would burn, long or short. The higher its quantity the better the quality and the longer it burns. Of course, the heating energy value would equally be high. Hence, the fixed carbon and calorific value are strictly the parameters of placing coals into different ranks. The volatile matter is equally important as it is given off as gas and vapour. It consists mainly of combustible gases such as hydrogen, carbon-monoxide, and methane, plus other hydrocarbons. Tar and incombustible gases such as carbon dioxide and steam are also evolved. The proportion of volatile constituents to fixed carbon in the result (Table 4.1) is high and this means that the fuel would burn quickly with a long smoky flame that is difficult to control. The high content of the volatile matter in the result (Table 4.1) demonstrates that the coal of the study area is of low rank. This is because the content of the volatile matter decreases with increase in coal rank [28].

The moisture content and ash content of coals are counter-productive. The higher the moisture and ash contents, especially the ash content the lesser the quality. They are contained in some measures in the various ranks of coal, though high to extreme in low rank coals. This may be due to their porous nature [29]. In the high rank coals they are very minimal. Also, this may be based on their little to no porosity. A common characteristic of lignite coal is the presence of abundant inherent moisture [30] within its carbonaceous matrix [31]. Moisture held within the coal itself is known as inherent moisture and is analyzed. The inherent moisture [32] is that fraction of the moisture content that is structurally contained in the material [33]. Moisture may occur in four possible forms within the coal, namely; surface moisture- water held on the surface of coal particles or macerals, hydroscopic moisture- water held by capillary action within the micro-fractures of the coal, decomposition moisture- water held within the coal' $\mathrm{s}$ decomposed organic compounds, and mineral moisture - water which comprises part of the crystal structure of hydrous.

\section{Conclusion}

In determining the rank of coal, the percentage of fixed carbon and calorific value is very critical. It has been established in this study that the degree of coalification a coal deposit undergoes would normally determine its percentage of fixed carbon and calorific value, and the quality. Having undergone maximum coalification, anthracite has the highest percentage of fixed carbon and calorific value, and is the best quality of coal. However, the reverse is true for lignite.This paper has established from the proximate analysis carried out on each of the samples collected from various locations at Maiganga coal mine that the Maiganga coal deposit has high percentage ash content, high percentage moisture content, and low percentage fixed carbon and low calorific value. The implication of this is that the Maiganga coal deposit belongs to a lower coal rank. Judging by the American Society for Testing Materials (ASTM) coal classification (Table 4.3), the values of the result of the analysis (Table 4.1) places the Maiganga coal in the lignite rank.

\section{Reference}

[1]. C.J. Varnell, J.V. Brahna, and K. Steele, The Influence of Coal Quality Variation on Utilization of Water from Abandoned Coal Mines as a Municipal Water Source, Mine Water and Environment, 23, 2004, 204-208.

[2]. T.K. Ghosh and M.A. Prelas, Coal, in T.K. Ghosh and M.A. Prelas, Energy Resources and Systems: Fundamentals and Non-Renewable Resources, 1(New York, Springer Science+Business Media B.V. 2009) 159-279.

[3]. B. Li, X. Zhuang, S. Zhao, Geological Controls on Coal Quality of the Yili Basin, Xinjiang, Northwest China, International Journal of Coal Geology, 131, 2014, 186-199.

[4]. F.B. Waanders, A. Govender, Mineral Associations in Coal and their Transformation during Gasification, Springer Science + Business Media B. V., 166, 2006, 67-691.

[5]. L.A. Amakin, Redox Conditions and the Transformation of Organic Matter in Coal, Coke and Chemistry, 51(4), 2008, $199-124$.

[6]. M.L. Ulanovskii, Metamorphism and Mineral Composition of Coal, Coke and Chemistry, 53(4), 2010, 124-128.

[7]. M.L. Ulanovskii, Chemical Aspects of Coal Metamorphism and the Formation of Low-Molecular Volatiles, Coke and Chemistry, 55(12), 2012, 439-443.

[8]. M.I. Bychev, G.I. Petrova, Effects of Coal Rank on the Composition of Organic Matter (Short Communication), Solid Fuel Chemistry, 45(2), 2011, 95-96.

[9]. J.G. Speight, Handbook of Coal Analysis (Hoboken, NJ: John Wiley \& Sons Inc., 2005).

DOI: 10.9790/0990-0501016774 www.iosrjournals.org $\quad$ wage


[10]. S.P. Schweinfurth, An Introduction to Coal Quality, in B.S. Pierce and K.O. Dennen (eds.), The Resource Assessment Overview: U.S. Geological Survey Professinoal Paper 1625 - F (Virginia: U.S. Geological Survey 2009) 16.

[11]. F. Goodarzi, Geology of Trace Elements in Coal, in D.J. Swaine and F. Goodarzi (eds.), Environmental Aspects of Trace Elements in Coal (Kluwer Academic Publishers 1995) 51-75.

[12]. J. Pešek and I. Sýkorová, A Review of the Timing of Coalification in the Light of Coal Seam Erosion, Clastic Dyke and Coal Clasts, International Journal of Coal Geology, 66, 2006, 13-34.

[13]. B. Fu, G. Liu, Y. Liu, S. Cheng, C. Qi, and R. Su, Coal Quality Characterization and its Relationship with Geological Process of the Early Permian Huainan Coal Deposits, Southern North China, Journal of Geochemical Exploration, 166, 2016, 33-44.

[14]. MMSD, Nigeria Mineral Projects: Exploration, Development and Exploration, Nigeria Geological Survey Agency, 2012 , 19-22.

[15]. E.V. Freidina, A.A. Botvinnik, and A.N. Dvomikova, Basic Principles of Coal Classification by Useful Quality, Journal of Mining Science, 47(5), 2011, 593-605.

[16]. N.G. Obaje, Geology and Mineral Resources of Nigeria, Lecture Notes in Earth Sciences (London: Springer-Verlag Berlin Heidelberg 2009) $57-76$.

[17]. M.E. Offodile, A Review of the Geology of the Cretaceous of the Benue Valley, in C.A. Kogbe (ed.), Geology of Nigeria (Lagos: Elizathern Publishers 1976).

[18]. J.D. Carter, W. Barber, E.A. Tait, and G.P. Jones, The Geology of Parts of Adamawa, Bauchi and Borno Provinces in the North Eastern Nigeria, Bulletin 30, Geological Survey of Nigeria, 1963, 11-96.

[19]. B.N. Ekwueme, Field Geology and Geological Map Production and Interpretation (Calabar: Bachudo Science Company Ltd 2004).

[20]. F.G.H. Byth, Geological Survey Map (London: Edwards Arnold Publishers Ltd 1976) 2-48.

[21]. V.K. Popov, Yu.M. Posokhov, I.L. Rachev, A.N. Zaostrovskii, Relationship between the Mineral Matter and Ash Contents of Coal fom the Bogastyr Strip Mine of the Ekibastuz, Solid Fuel Chemistry, 45(2), 2011, 128-134.

[22]. L.V. Kopeliovich, Oxide Content in Ash and the Petrographic Composition and Caking Properties of Coal, Coke and Chemistry, 53(9), 2010, 330-332.

[23]. V.L.V. Fallavena, C.S. Abreu, T.D. Inácio, C.M.N. Pires, M. Ferret, L.S. I.D. Fernandes, and R.M. Tarazona, Determination of Mineral Matter in Brazilian Coals by Thermal Treatments, Fuel Processing Technology, 125, 2014, 41-50.

[24]. H.C. Okolo and M.C. Mkpadi (eds.), Nigeria Coal: A Resource for Energy and Investments (Abuja: Raw Materials Research and Development Council 1996) 3-265.

[25]. S. Ghosh, R. Chatterjee, and P. Shabker, Estimation of Ash, Moisture Content and Detention of Coal Lithofacies from Well Logs Using Regression and Artificial Neural Network Modelling, Fuel, 177, 2016, 279-287.

[26]. B.P. Kiselev, Role of the Coal Rank in the Formation of Coking Batch, Coke Chemistry, 51(5), 2008, 159-162.

[27]. B. Tetmez, B. Hozatli, A.K. Cengiz, An Overview of Turkish Lignite Qualites by Logistics Analysis, Journal of Coal Science and Engineering, 19(2), 2013, 113-118.

[28]. W. Hua, Z. Xinguo, Coal Rank Distribution and Implications for Structural and Geothermal Controls on Coalification: Case Study from the Cevennes Basin, Massif Central, France, International Journal of Coal Geology, 66, 2006, 1-12.

[29]. K.C. Xie, Geological Characteristics of Coal, in K.C. Xie, Structure and Reactivity of Coal (New York: Springer-Verlag Berlin Heidelberg 2015) 1-27.

[30]. X. Jing, K. Jing, Z. Li, X. Liu, Y. Zhang, L. Chang, and W. Bao, Thermal Effect during Re-Adsorption of Dewatered Lignite, Journal of Thermal Analytic Calorimetric, 48(5), 2015, 313-319.

[31]. V. Prationo, J. Zhang, J. Wang, L. Zhang, Influence of Inherent Moisture on the Ignition and Combustion of Wet Victorian Brown Coal in Air-Firing and Oxy-Fuel Modes: The Volatile Ignition and Flame Propagation, Fuel Processing Technology, 138, 2015, 670-679.

[32]. R. Sakurovs, C. Lewis, and L. Wiberley, Effect of Heat and Moisture on the Surface Titratability and Size Distribution of Victorian Brown Coal, Fuel, 172, 2016, 124-129. 